УДК 342.8

DOI https://doi.org/10.32843/2663-52402019-11-5

\section{шишак A.O.}

аспірант кафредри парламентаризму та політичного менеджменту

Національна академія державного управління при Президентові України

\begin{abstract}
У статті проведено дослідження передвиборних програм кандидатів на пост Президента України щодо наявності і якісного складу інноваційних цілей. Визначено та обгрунтовано поняття «інноваційна ціль» у текстах передвиборних програм кандидатів на пост Президента України, здійснено відбір та оцінювання їх якісного складу з використанням критеріїв SMART, встановлено недоліки сучасного стану передвиборних програм. За результатами дослідження сорормовано висновки щодо необхідності нормативного закріплення статусу передвиборної програми та вимог до ії змісту та структури.

Ключові слова: передвиборна програма, інноваційна иіль, кандидат на пост Президента України, інновація, критерії SMART.
\end{abstract}

В статье проведено исследование предвыборных программ кандидатов на пост Президента Украины относительно наличия и качественного состава инновационных целей. Определено и обосновано понятие «инновационная цель» в текстах предвыборных программ кандидатов на пост Президента Украины, осуществлен отбор и оценка их качественного состава с использованием критериев SMART, установлены недостатки современного состояния предвыборных программ. По результатам исследования сформированы выводы о необходимости нормативного закрепления статуса предвыборной программы и требований к ее содержанию и структуре.

Ключевые слова: предвыборная программа, инновационная цель, кандидат на пост Президента Украины, инновация, криmepuu SMART.

The article conducted a study of the election programs of candidates for the post of President of Ukraine regarding the presence and quality of innovative goals. The concept of "innovative goal" in the texts of electoral programs of candidates for the presidency of Ukraine has been defined and substantiated, their quality composition has been selected and evaluated using SMART criteria, the shortcomings of the current state of electoral programs have been established. According to the results of the study, conclusions were drawn up on the need for a normative consolidation of the status of the electoral program and the requirements for its content and structure.

Key words: election program, innovation goal, candidate for the post of President of Ukraine, innovation, SMART criteria.
Постановка проблеми у загальному вигляді. Передвиборні програми кандидатів на пост Президента України науковцями досліджуються науковцями в різних аспектах із використанням широкого кола методів. I чим більше досліджень передвиборних програм проводиться, тим більше висвітлюється абстрактний характер їх змісту та декларативність їх положень. Крім того, у програмах кандидатів на пост Президента України відсутні чіткі механізми досягнення задекларованих цілей.

Неналежному створенню вказаних програм сприяють нечіткі вимоги законодавства щодо структури передвиборних програм та їх змісту, відсутність певних стандартів їх формування. Це призводить до того, що ці програми містять лише голослівні обіцянки, пропозиції та суспільно-політичні декларації, лозунги та заклики, що спрямовані на несвідомого виборця. Тому виборець, що має власні критерії щодо обрання кандидата, не читає передвиборні програми кандидатів на пост Президента України та не робить свій вибір орієнтуючись на ці програми. Чому так сталось, що такий потужний інститут виборчого та конституційного права не має дієвого впливу на вибір електорату? Цьому $€$ пояснення, що містяться в самій природі походження передвиборних програм.

Законодавством України не встановлено правової відповідальності обраної особи за невиконання передвиборної програми, що сприяє їх неналежному змістовому наповненню. Також регламентований пунктом З частини першої статті 51 Закону України «Про вибори Президента України» від 05.03.1999 № 474-XIVв редакції від 28.02.2019 року [1] обсяг передвиборної програми кандидата - до дванадцяти тисяч друкованих знаків - не сприяє їх деталізації, а тому тексти передвиборних програм в основному декларують напрями та цілі діяльності, містять переважно політичні лозунги та заклики.

Передвиборна програма законодавством визначається як засіб політичного розмежування та контролю за намірами кандидатів (для цього програма підлягає реєстрації у виборчих органах) та як засіб передвиборної агітації (саме тому законодавство містить гарантії щодо оприлюднення програми та її використання під час передвиборної агітації) [3, с. 30-36]. Але як засіб передвиборної 
агітації програма кандидата у Президенти України через вказані вище причини виявляється недостатньо переконливою і зрозумілою виборцю, а тому кандидати використовують більш дієві засоби та методи агітації і країна на декілька місяців поринає в передвиборну гонитву за виборцем із відповідними наслідками для економіки. Отже, нині уваги дослідників потребують передвиборні програми кандидатів на пост Президента України з метою їх вдосконалення, однозначного доктринального пояснення інституту передвиборних програм у виборчому праві, внесення змін до законодавства, підвищення виборчої культури суспільства.

До сфери наукових інтересів автора належать теоретичні засади дослідження становлення та формування інноваційної діяльності в публічному управлінні України i, зокрема, встановлення наявності інноваційних цілей у текстах передвиборних програм кандидатів на пост Президента України.

Актуальність статті полягає в обґрунтуванні визначення поняття «інноваційна ціль» у текстах передвиборних програм кандидатів на пост Президента України, що дає змогу дослідити наявність вказаних цілей та оцінити їх якісний складу з використанням критеріїв SMART.

Аналіз останніх досліджень і публікацій. Передвиборні програми кандидатів на пост Президента України досліджували вітчизняні науковці: концепт реформування політичної сфери - Варзар І.М., Тімашова B.M. [2, с. 5-12]; статус передвиборних програм - Бабін Б.В. [3, с. 30-36], Берназюк І.М. [4, с. 19-23]; питання щодо євроатлантичної та європейської інтеграції - Гладенко В.М. [5, с. 102-107]; проблеми конституційного інституту референдуму - Дерев'янко С.M. [6, с. 61-72]; принципи текстотворення Кондратенко Н.В. [7, с. 124-131]; аспекти національної безпеки - Костенко Г.Ф. [8, с. 140-144], порівняльний аналіз передвиборних програм кандидатів - Підкова І.3. [9, с. 246-254] та інші.

Вагомий внесок у дослідження проблематики інновацій у сфері політики та управління здійснювали зарубіжні науковці: моделі інновацій та дифузії в політичних дослідженнях - Вільям Д. Беррі [10, с. 263-308]; різноманітності трансформативної інноваційної політики в новій політичній парадигмі - Діркс Гійс, Хенрік Ларсен, Фред Стюард [11, с. 880-894]; інновації у сфері політики Ерккі Каро, Райнер Каттель [12, с. 123-150]; спільні інновації в державному секторі - Яків Торфінг [13, с. 1-11]; цілі сталого розвитку як інновації в управлінні - Валентина Брогна [15, с. 441]; сприйняття політики в контексті наукових інновацій - Торбйорн Фрібер, Магнус Енгландер [15, с. 1-7] та інші.

Виділення невирішених раніше частин загальної проблеми. Сьогодні актуальних досліджень щодо виявлення інноваційних цілей у передвиборних програмах кандидатів на пост Президента України вітчизняними та зарубіжними дослідниками проведено не було. Саме тому дане дослідження $€$ необхідним та перспективним, оскільки його результат дозволить встановити, чи є в намірах кандидатів, що викладені в текстовому наповненні передвиборних програм кандидатів на пост Президента України, інноваційні цілі, наскільки вони $є$ якісними та чи потребують передвиборні програми кандидатів на пост Президента України змін і вдосконалення.

Мета статті. Обґрунтування теоретичних засад інноваційної діяльності в публічному управлінні України, визначення поняття «інноваційна ціль» та встановлення наявності інноваційних цілей у текстах передвиборних програм кандидатів на пост Президента України на основі сформованого визначення та оцінювання їх якісного складу з використанням критеріїв SMART.

Виклад основного матеріалу. На основі аналізу наукових праць із проблеми дослідження, нормативно-правових документів та текстів передвиборних програм кандидатів на пост Президента України, що розміщені на їх сторінках на сайті ЦВК України за електронною адресою: http://www.cvk.gov.ua/pls/ vp2019/WP001, автором було обґрунтовано та визначено поняття «інноваційна ціль», проведено відбір інноваційних цілей і оцінено їх якісний склад із використанням критеріїв SMART.

У Законі України «Про інноваційну діяльність» № 40-IV від 04.07.2002 визначено термін «інновації» - новостворені (застосовані) і (або) вдосконалені конкурентоздатні технології, продукція або послуги, а також організаційно-технічні рішення виробничого, адміністративного, комерційного або іншого характеру, що істотно поліпшують структуру та якість виробництва і (або) соціальної сфери [16].

Термін «innovatio» з латинської мови перекладається як інновація - оновлення. 3 англійської «innovation» перекладається на українську як «введення нового» або «введення новацій». Практичне застосування новації від її створення та поширення як нового продукту або послуги є нововведенням (інновацією). Під «новацією» розуміють винахід, відкриття, новий метод, технологію. 
Сучасна наукова література представлена множинністю підходів до визначення поняття «інновація», оскільки інновація виникає внаслідок використання результатів наукових досліджень і розробок, які спрямовані на вдосконалення процесів виробничої діяльності, економічних, правових і соціальних відносин у різних сферах діяльності суспільства. У залежності від цілей аналізу термін «інновація» набуває різних значень.

У науковій літературі виділяють два основних напрями визначення поняття «інновація»:

1) статичний, коли інновація виступає як результат інноваційного процесу (продукт) у вигляді нового методу, техніки, технології, що впроваджується на ринку (Е. Фон Хіппель, Х. Ріпс, Р Б.Твісс, Х. Барнет, «Рекомендації Фраскаті» (2015) та «Керівні принципи збору, звітності та використання даних про інновації» (Осло, 2018));

2) динамічний, коли в динаміці розглядається процес комерціалізації і поширення нових виробів, технологій, принципів замість існуючих, (дослідження, проектування, розроблення, організація виробництва), (П. Лелон, Й. Шумпетер, Д. Бессант, Б. Санто, О. Лапко, Д. Черваньов та інші.) [17, с. 35].

Отже, термін «інновація» можна визначити як комерційне застосування нових та більш продуктивних технологій, які існують у формі нових або вдосконалених товарів чи послуг, нових організаційних, технічних, управлінських, економічних, соціальних рішень та значно змінюють обсяги та якість виробництва і реалізації; (продукт) та техніко-економічний процес вироблення, комерціалізації та поширення нового виробу, процесу або технології (процес).

Узагальнюючи вищезазначені наукові підходи, слід виокремити ознаки, що є характерними для інновацій:

1) інновація $€$ новим або вдосконаленим продуктом чи процесом, доцільним і корисним під час застосування на практиці;

2) предметом інновацій можуть бути вироби, технології, організація виробництва, управління;

3) інновації є найважливішим засобом реалізації цілей розвитку суспільства.

Метою (ціллю) інновації $€$ забезпечення невпинного суспільного розвитку, ефективного та рентабельного виробництва, оволодіння найновішими науково-технічними досягненнями, широке використання загальнолюдського інтелектуального надбання, вдосконалення економічних, правових та соціальних відносин в усіх сферах діяльності суспільства [18, с. 270].
Тексти передвиборних програм кандидатів на пост Президента України містять їх наміри щодо здійснення діяльності на посту глави держави та інформують суспільство про цілі, способи, методи і прогнозований результат у разі їх досягнення. Відповідність цілей в передвиборній програмі кандидата прагненням та очікуванням певного кола виборців спонукають останніх робити свій вибір на його користь. Ціль у передвиборних програмах $€$ лише тоді інноваційною, коли вона спрямована на: соціальні нововведення, які узгоджують економічні та соціальні потреби суспільства, управлінські нововведення, що дозволяють адекватно реагувати на зміни в зовнішньому середовищі, освоєння нових продуктів, послуг, методів та технологічних процесів, що відповідають вимогам науково-технічного прогресу.

Отже, можемо визначити інноваційну ціль у текстах передвиборних програм кандидатів на пост Президента України як нововведення організаційно-технічного, управлінського, соціально-економічного спрямування, що здатне забезпечити суспільний прогрес, освоєння нових продуктів, послуг, методів та технологічних процесів, розвивати та вдосконалювати економічні, правові та соціальні відносини в суспільстві.

Щодо визначення передвиборної програми, то, на думку автора, найповнішим $€$ визначення, дане в Юридичній енциклопедії [19, с. 236]: «Передвиборна програма - офіційно зареєстрований письмовий документ політичної партії, виборчого блоку партій, що висунули список кандидатів у депутати чи на виборну посаду, або окремих кандидатів, який містить основні напрями їх громадсько-політичної діяльності після обрання. Подання передвиборної програми, викладеної державною мовою обсягом, який передбачений відповідним виборчим законом, є обов'язковоюумовою реєстрації кандидатів удепутати у відповідній виборчій комісії. Передвиборна програма належить до матеріалів передвиборної агітації. На неї розповсюджуються загальні вимоги до цих матеріалів, визначені законами про вибори. Передвиборна програма не повинна суперечити Конституції України, законам України чи містити неправдиві дані або комерційну рекламу. Після реєстрації передвиборної програми партія (блок) кандидат може виступати зі своєю програмою, яка обговорюється під час виборчої кампанії громадянами, їх об'єднаннями, колективами підприємств, установ і організацій з використанням різних форм та засобів агітації...»

Отже, передвиборна програма кандидата на пост Президента України - це офіційний 
політико-правовий документ ненормативного характеру, що подається до Центральної виборчої комісії для реєстрації кандидата на пост Президента України та $€$ засобом спеціального інформаційного забезпечення виборів, а також може використовуватися як інструмент передвиборної агітації, в якому послідовно викладені суспільно-управлінські реформи, які зобов'язується виконати кандидат у разі отримання перемоги на виборах, та загальна стратегія їх реалізації.

Передвиборна програма $є$ основою правотворчості Президента України, оскільки, голосуючи за відповідного кандидата на пост глави держави, народ обирає напрями майбутнього розвитку країни та стратегію їх реалізації, способи досягнення поставлених цілей, які визначені в передвиборній програмі.

Проте відсутність законодавчих вимог до змісту передвиборної програми кандидата на пост Президента України на практиці призводить до того, що в основному кандидати використовують загальні гасла та лозунги, які часто не містять чіткої стратегічної позиції відповідного кандидата, а тому можуть призвести до маніпулювання свідомістю громадян із метою переконання їх у здійсненні бажаного вибору [4, с. 21].

Стосовно структури передвиборної програми кандидата на пост глави держави, то, як зазначається в науковій літературі, вони будуються за блоками-напрямками суспільного розвитку, серед яких $€$ державне будівництво, духовне життя, правова сфера, економічне життя, соціальна сфера, зовнішня політикатощо. Усіці розділи маютьмістити серйозні обґрунтування того чи іншого шляху розвитку сфери життя в баченні кандидата, включаючи математичне пояснення [20, с. 33-42].

Щодо можливості запровадження обов'язкового виконаннязавдань, викладенихупередвиборній програмі кандидатом на пост Президента України, який отримав перемогу на виборах (оскільки такий обов'язок витікає з положень ст. ст. 1, 3, 6, 8, 69 Конституції України), то необхідно зазначити, що для цього важливою $€$ не тільки наявність організаційного механізму, але й можливість застосування до глави держави відповідальності. Відсутність такої можливості підтверджена постановою Вищого адміністративного суду України від 21 липня 2011 р. №П/9991/367/11 [21], яка ґрунтувалася на дуже своєрідному тлумаченні положень розділу VIII «Передвиборна агітація» Закону України «Про вибори Президента України», передвиборна програма кандидата на пост Президента України була визнана як «засіб агітації», при цьому суд вказав, що «передвиборна програма кандидата на пост Президента України не $є$ законодавчим актом». Тому суд визнав, що в умовах невиконання Президентом України власної передвиборної програми «підстав для визнання бездіяльності Президента України протиправною немає» [3, с. 34].

Отже, основними недоліками сучасного стану передвиборної програми кандидата на пост Президента України є: 1) невизначеність вимог до змісту та структури передвиборної програми кандидата на пост глави держави; 2) відсутність законодавчо визначеного механізму забезпечення виконання завдань, які міститьпередвиборнапрограма, через несформованість її статусу як основного програмного документа майбутнього глави держави.

На момент проведення дослідження на сайті ЦВК розміщено 44 (сорок чотири) програми кандидатів на пост Президента України.

Дослідження проводилось у два етапи. На першому етапі проводився відбір інноваційних цілей, на другому - оцінювався їх якісний склад.

Для виконання першого етапу було узагальнено на систематизовано дані стосовно інноваційних цілей, заявлених у текстах передвиборних програм кандидатів на пост Президента України. Відбір інноваційних цілей був здійснений на основі визначення, що сформоване і наведено вище. Для рівномірного та об'єктивного оцінювання було визначено кількість цілей - три на кожну програму. Якщо програми містили більшу кількість інноваційних цілей, здійснювалась вибірка трьох, які мали кращу оцінку за критеріями SMART. Програми, що не містили інноваційних цілей, відповідно позначались і не враховувались в оцінюванні.

Для другого етапу - якісного дослідження інноваційних цілей, в текстах передвиборних програм кандидатів на пост Президента України автором було обрано критерії SMART, виходячи з того, що суспільно-управлінські зміни, які $€$ основою положень програми, потребують обґрунтування та оцінювання. Чітко сформовані інноваційні цілі в передвиборній програмі, які можна оцінити, вказують на планування досягнення результату в діяльності на посту глави держави, що якісно вирізняється від банальної передвиборної обіцянки.

Критерії SMART - мнемонічна абревіатура, використовувана для визначення цілей і постановки завдань. Уперше термін був вжитий в 1965 році в роботі П. Мейєра, який вивчав проблематику ефективного менеджменту та конкретно визначений в роботах Джорджа T. Дорана [22, с.35], Херсі Пола, Кеннет Х. Бланшара і Дьюі Е. Джонсона [23, с. 51]. 
Незважаючи на те, що в проектному плануванні SMART - абревіатура, в англійській мові слово «smart» має значення «розумний». Переклад у даному випадку відіграє важливу роль, тому що розкриває суть: постановка мети повинна бути розумною. Критерії означають:

- S - конкретний (specific)

- М - вимірний (measurable)

- A - досяжний (attainable)

- R - актуальний (relevant)

- T - обмежений у часі (time-bound)

Під час проведення якісного оцінювання кожної інноваційної цілі за допомогою критеріїв SMART кожна ціль отримувала один бал за умови відповідності нижченаведеним критеріям.

Конкретність - мета має бути зрозумілою та однозначною. Для того, щоб мета стала специфічною, має бути означено, що точно очікується, чому це важливо, кого це стосується, де це буде відбуватися.

Вимірюваність - $є$ вимірювані показники для визначення прогресу досягнення мети. Якщо прогрес у досягненні мети не можна виміряти, то неможливо знати, чи $€$ рух у напрямку успішного завершення.

Досяжність - мета має бути реалістичною. Під час створення мети має бути передбачено наявність необхідних ресурсів, часу, компетенцій.

Доцільність (цей термін краще розкриває суть ніж «актуальність») - має бути важливим для загальної мети, слушним, результат має бути застосовним у поточному, соціо-економіко-технічному середовищі.

Обмеженість у часі - наявність кінцевої дати виконання. Окреслює часові рамки в досягненні мети.

У результаті дослідження було отримано дані, що визначають якісний склад запропонованих інноваційних цілей у передвиборних програмах. На основі аналізу отриманого результату дослідження встановлено:

1. 18 передвиборних програм кандидатів на пост Президента України із 44 містять по три інноваційних цілі - 41\% (рис. 1).

2. У 24 передвиборних програмах кандидатів на пост Президента України відсутні інноваційні цілі, які відповідають умовам дослідження - 59\%.

3. Узагальнені показники якості інноваційних цілей у передвиборних програмах кандидатів на пост Президента України в балах зведено в таблицю 1 та зображено на рисунку 2. Із них:

- 1 передвиборна програма має високий показник якості інноваційних цілей (більше ніж10 балів);

- 5 передвиборних програм мають показник якості інноваційних цілей вище середнього (від 8 до 10 балів);

- 9 передвиборних програм мають середній показник якості інноваційних (від 6 до 7 балів);

Таблиця 1

Узагальнені показники якості інноваційних цілей у передвиборних програмах кандидатів на пост Президента України, в балах

\begin{tabular}{|l|c|c|c|c|c|c|c|}
\hline Бали (максимум 15) & 11 & 9 & 8 & 7 & 6 & 5 & 2 \\
\hline Програми & 1 & 3 & 2 & 7 & 2 & 2 & 1 \\
\hline Відсоток & $5,56 \%$ & $16,67 \%$ & 11,11 & 38,89 & 11,11 & 11,11 & $5,56 \%$ \\
\hline
\end{tabular}

Джерело: складено автором самостійно на основі даних [24]

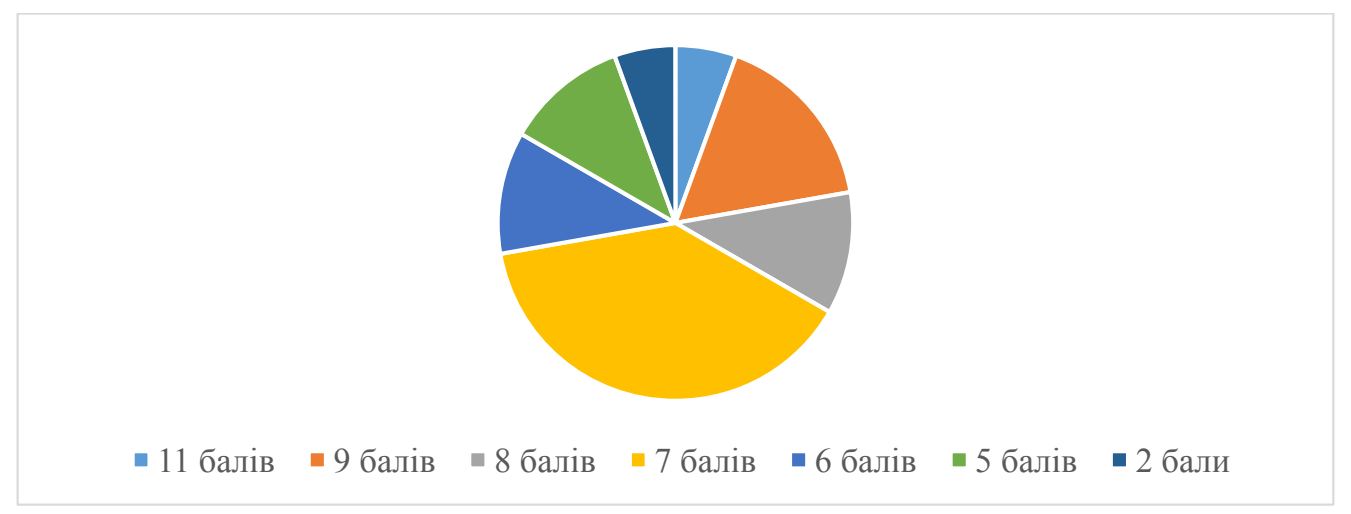

Рис. 2. Показники якості інноваційних цілей у передвиборних програмах кандидатів на пост Президента України, відсотки

Джерело: складено автором самостійно на основі даних [24] 
- 3 передвиборних програм мають низький показник якості інноваційних (5 та менше балів).

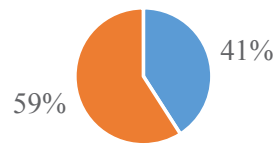

Рис. 1. Наявність інноваційних цілей у передвиборних програмах кандидатів на пост Президента України

Джерело: складено автором самостійно на основі даних [24]

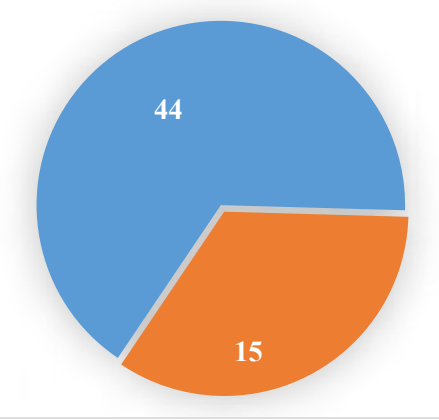

Рис. 3. Співвідношення кількості програм із позитивною оцінкою якості інноваційних цілей у передвиборних програмах до їх загальної кількості

Джерело: складено автором самостійно на основі даних [24]

У відношенні до загальної кількості передвиборних програм показники якості інноваційних цілей складають:

- 15 (34\%) передвиборних програм із 44 мають позитивні показники оцінки наявних у них інноваційних цілей (рис. 3):

- $6(13,6 \%)$ передвиборних програм із 44 мають високий і вище середнього показники оцінки якості наявних у них інноваційних цілей;

- $9(20,4 \%)$ передвиборних програм із 44 мають середній показник оцінки якості наявних у них інноваційних цілей;

- $3(6,8 \%)$ передвиборних програм із 44 мають низький показник оцінки якості наявних в них інноваційних цілей.

Висновки. Таким чином, обґрунтувавши визначення поняття «інноваційна ціль» у текстах передвиборних програм кандидатів на пост Президента України, ми змогли дослідити наявність вказаних цілей та оцінити їх якісний склад із використанням критеріїв SMART, що дозволило сформулювати такі висновки:

1. Майже $60 \%$ передвиборних програм кандидатів на пост Президента України не містять інноваційних цілей, зокрема не спрямовані на реалізацію загальнонаціональних інтересів, структурних змін в економіці, підвищення кон- курентоспроможності країни у глобальному просторі. Це свідчить про те, що іх автори безвідповідально ставляться до створення передвиборних програм та не враховують зміни сучасних виборчих уподобань.

2. Усього 6 (13,6\%) передвиборних програм із 44 мають високий і вище середнього показник оцінки якості наявних у них інноваційних цілей, зокрема конкретне і актуальне змістове наповнення та дієві механізми реалізації пропонованих намірів. Це вказує на те, що лише незначною частиною розробників було враховано критерії SMART під час формування положень та напрямів діяльності в передвиборних програмах. Такий підхід дозволяє спонукати навіть інертну частину виборців робити вибір за того кандидата, який має переконливу, доступну для сприйняття та інноваційно спрямовану передвиборну програму, що відповідає вимогам часу і пріоритетним напрямам розвитку держави та суспільства в сучасному цифровому світі.

3. На даний час передвиборні програми кандидатів на пост Президента України внаслідок невизначеності вимог до їх змісту та структури, відсутності законодавчо визначеного механізму забезпечення виконання викладених у них напрямів, цілей та завдань належно не застосовуються як програмний документ глави держави та засіб передвиборної агітації.

Усунути ці недоліки можливо, визначивши в окремій статті Закону України «Про вибори Президента України» статус передвиборної програми як головного програмного документа діяльності новообраного глави держави; визначити вимоги до змісту та структури передвиборної програми. В Указі Президента України «Про щорічні послання Президента України до Верховної Ради України» закріпити, що під час підготовки щорічних послань глави держави до парламенту мають враховуватися його програмні завдання, визначені в передвиборній програмі.

Перспективи подальших наукових досліджень вбачаємо в науковому обґрунтуванні збільшення регламентованого Законом України «Про вибори Президента України» обсягу передвиборної програми кандидата з метою деталізації її положень, обґрунтування визначених в ній інноваційних цілей, включно з математичним та схематичним поясненням.

\section{ЛІТЕРАТУРА:}

1. Про вибори Президента України : Закон України від 05.03.1999 № 474-XIV. Відомості Верховної Ради України. 1999 р. № 14. Стаття 81.

2. Варзар І.М., Тімашова В.М. Концепт реформування політичної сфери у передвиборних програмах 
кандидатів на пост Президента України (2014р.) Наукові праці МАУП. 2014. Вип. 3(42). С. 5-12.

3. Бабін Б.В. Передвиборні програми у правових механізмах програмного регулювання. Юридичний вісник. 2013. №. 2. С. 30-36.

4. Берназюк I.М. Передвиборча програма кандидата на посаду президента України: поняття та стан правового регулювання. Актуальні проблеми вітчизняної юриспруденції. 2017. С. 19-23.

5. Гладенко В.М. Позиції кандидатів у президенти 2010 р. щодо євроатлантичної та європейської інтеграції. Науковий вісник Волинського національного університету імені Лесі Українки. Міжнародні відносини. 2012. № 20. С. 102-107.

6. Дерев'янко С.М. Конституційний інститут референдуму у передвиборних програмах кандидатів на пост Президента України. Актуальні проблеми вдосконалення чинного законодавства України. 2010. Вип. 23. С. 61-72.

7. Кондратенко Н.В. Принципи текстотворення політичної програми як мовленнєвого жанру політичного дискурсу. Записки з українського мовознавства. 2017. Вип. 24(2). С. 124-131.

8. Костенко Г.Ф. Передвиборні програми в Україні: аспект національної безпеки. Науковий вісник Дипломатичної академії України. 2008. Вип. 14 C. $140-144$.

9. Підкова І. Президентські вибори 1991 р. в Україні: порівняльний аналіз передвиборчих програм кандидатів. Вісник Прикарпатського університету. Історія. 2011. Вип. 20. С. 246-254.

10. Berry F. S., Berry W. D. Innovation and Diusion Models in Policy Research. Theories of the policy process. Routledge, 2018. P. 263-308.

11. Diercks G., Larsen H., Steward F. Transformative innovation policy: Addressing variety in an emerging policy paradigm. Research Policy. 2019. T. 48. № 4. C. 880-894.

12. Karo E., Kattel R. Innovation and the state: towards an evolutionary theory of policy capacity. Policy Capacity and Governance. Palgrave Macmillan, Cham, 2018. C. 123-150.
13. Torfing J. Collaborative innovation in the public sector: the argument. Public Management Review. 2019. T. 21. № 1. P. 1-11.

14. Brogna V. Governing through goals: Sustainable Development Goals as governance innovation. International Affairs. 2018. T. 94. C. 441.

15. Friberg T., Englander M. Taking Policy for Granted in the Context of Scientific Innovation. International Journal of Qualitative Methods. 2019. T. 18. C. 1-7.

16. Про інноваційну діяльність : Закон України від 04.07.2002 № 40-IV. Відомості Верховної Ради України. 2002. № 36. Стаття 266.

17. Знаменський І.О. Сучасні підходи до визначення сутності інновацій. Матеріали Інтернетконореренції «Наука в інфрормаційному просторі», 15-16 жовтня 2008 р. Дніпропетровськ : ПДАБА, 2008. C. 34-37.

18. Єрмолаєва В.В. Теоретичні основи дослідження інновацій / В.В. Єрмолаєва. Вісн. нац. ун-ту «Львів. політехніка». Пробл. економіки та упр. 2010. № 683. C. 268-273.

19. Юридична енциклопедія: В 6 т. / Редкол. : Ю.С. Шемшученко (відп. ред.) та ін. Київ : «Укр. енцикл.», 2003. Т. 5. 736 с.

20. Ворона П. Передвиборчі програми політичних партій: сучасний етап розвитку громадянського суспільства. Актуальні проблеми державного управління. 2008. № 2. С. 33-42.

21. Постанова Вищого адміністративного суду України від 21/07.2011, № П/9991/367/11. URL : http://reyestr.court.gov.ua/Review/17313305.

22. Doran G. T. There'sa SMART way to write management's goals and objectives. Management review. 1981. T. 70. № 11. C. 35-36.

23. Hersey P., Blanchard K. H., Johnson D. E. Management of organizational behavior. Upper Saddle River, NJ : Prentice hall, 2007. T. 9.

24. Кандидати на пост Президента України. Центральна виборча комісії України. Вибори президента України 2019. URL : https://cvk.gov.ua/pls/ vp2019/wp003pt001f01=719.html. 